\title{
Multiple viral infection in Penaeus monodon shrimp postlarvae in an Indian hatchery
}

\author{
Subramaniyan Manivannan, Subhendu K. Otta, Indrani Karunasagar, Iddya Karunasagar* \\ Department of Fishery Microbiology, University of Agricultural Sciences, College of Fisheries, Mangalore 575002 , India
}

\begin{abstract}
Moribund Penaeus monodon postlarvae (PL8-PL10) in a hatchery in India were found to be simultaneously infected by 3 different viruses. They were highly infected with monodon baculovirus (MBV) and hepatopancreatic parvovirus (HPV) by histology and with white spot syndrome virus (WSSV) by non-nested polymerase chain reaction (PCR). Apparently healthy postlarvae tested from the same hatchery were positive for MBV and WSSV by nested PCR only. Tissue sections of such postlarvae did not show any histopathological changes. The simultaneous occurrence of these 3 viruses in hatchery-reared postlarval $P$. monodon is being reported for the first time.
\end{abstract}

KEY WORDS: MBV - HPV - WSSV - Shrimp postlarvae · Penaeus monodon · Mortality · PCR · Histopathology

Resale or republication not permitted without written consent of the publisher

The shrimp farming industry in the 1980s grew phenomenally due mainly to technological breakthroughs and high profitability. However viral diseases have reduced shrimp production since 1991, and thus have emerged as a major constraint to the growth of shrimp aquaculture (Leung \& Tran 2000).

Mortality of shrimp larvae in hatcheries often occurs because of variable biotic and abiotic factors, with biotic factors playing a more important role. In India, mass mortality of shrimp larvae due to antibiotic resistant Vibrio harveyi (Karunasagar et al. 1994) and larval mortalities in hatcheries due to monodon baculovirus (MBV) (Ramasamy et al. 1995) have been recorded. MBV infection has also been reported in most hatcheries and growout ponds in other south-east Asian countries (Lightner et al. 1992). MBV has been implicated in mass mortalities in shrimp that are cultured at high densities (Fulks \& Main 1992).

\footnotetext{
${ }^{*}$ Corresponding author. E-mail: mircen@sancharnet.in
}

Hepatopancreatic parvovirus in shrimp was first reported from Penaeus merguiensis and $P$. indicus by Chong \& Loh (1984) and from P. chinensis by Lightner \& Redman (1985). It was subsequently found to be widely distributed in several penaeid species from many parts of the world (Lightner 1996) including $P$. monodon in Thailand (Flegel et al. 1992).

In recent times, white spot syndrome virus (WSSV) has created havoc in shrimp farms and this has resulted in great economic losses worldwide. This virus has also been detected in shrimp larvae (Otta et al. 1999) and several carrier animals (Hossain et al. 2001) in India. In this communication we report from a hatchery along the west coast of India severe mortality of postlarvae associated with simultaneous infection by the 3 viruses described above.

Materials and methods. Sample collection: Mass mortality of postlarvae (PL8-PL10) was reported by a hatchery producing 60 million larvae $\mathrm{yr}^{-1}$. Out of 6 tanks of 10 ton capacity, 4 showed mass mortality. A minimum of 100 postlarvae were collected from each tank for histopathology and polymerase chain reaction (PCR). Healthy postlarvae (i.e. from tanks not showing any mortality) and diseased postlarvae were collected separately. Samples were immersed in Davidson's fixative for histopathology. For PCR, the samples were collected in $70 \%$ ethanol.

Histopathology: For histopathology, samples were processed as described by Bell \& Lightner (1988, p. 2-6). Briefly, the sections were deparaffinised, rehydrated in an alcohol series and then stained with hematoxylin and eosin.

PCR analysis: Postlarvae preserved in $70 \%$ ethanol were rehydrated in distilled water for $1 \mathrm{~h}$. Extraction of viral DNA was carried out as described earlier (Otta et al. 1999). Twenty-five whole postlarvae were sub-sampled for DNA extraction. Portions of the same DNA extract were used for the amplification of both MBV 
and WSSV. For WSSV detection, nested PCR primers and a protocol described earlier (Hossain et al. 2001) giving products of 486 and $310 \mathrm{bp}$ were used. For MBV detection, the nested PCR protocol and primers described by Belcher \& Young (1998) yielding products of 533 and $361 \mathrm{bp}$ were used with minor modification. Specifically, the PCR program for the non-nested reaction consisted of an initial delay at $94^{\circ} \mathrm{C}$ for $5 \mathrm{~min}$, followed by 30 cycles at $94^{\circ} \mathrm{C}$ for $30 \mathrm{~s}, 65^{\circ} \mathrm{C}$ for $30 \mathrm{~s}$ and $72^{\circ} \mathrm{C}$ for $30 \mathrm{~s}$, with a final extension at $72^{\circ} \mathrm{C}$ for $5 \mathrm{~min}$. For the nested PCR reaction, $0.5 \mu \mathrm{l}$ of the non-nested reaction product was taken as DNA template with all other components added in the concentrations given for the non-nested reaction. Cycling conditions for the nested reaction were similar to the non-nested reaction except that the annealing step was performed at $60^{\circ} \mathrm{C}$.

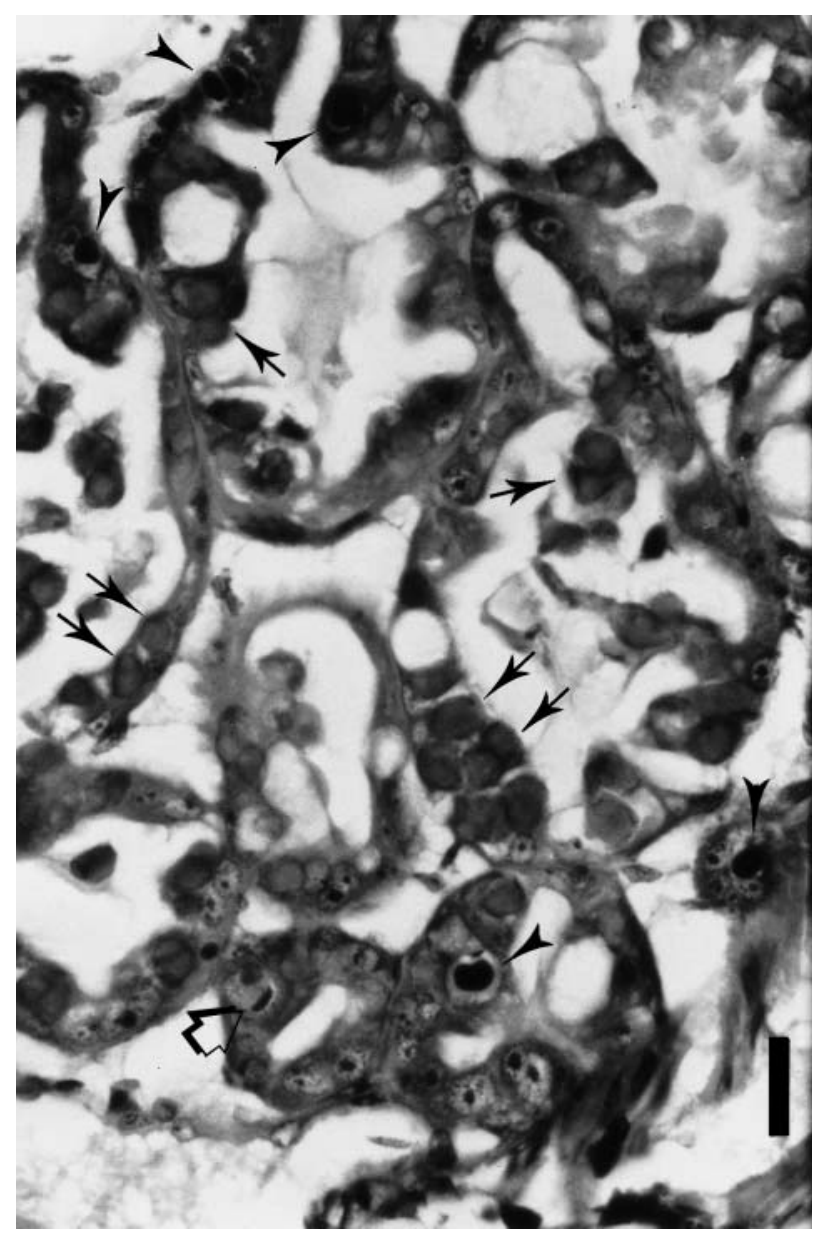

Fig. 1. Penaeus monodon. Photomicrograph of a histological section of hepatopancreatic tissue of infected postlarval $P$. monodon. Arrowheads indicate cells with strongly basophilic intranuclear inclusion bodies indicative of hepatopancreatic parvovirus (HPV) infection. Open arrow indicates a cell with developing inclusions. Arrows indicate eosinophilic multiple occlusion bodies characteristic of MBV infection (H\&E stained). Scale bar $=22 \mu \mathrm{m}$
All PCR reactions were carried out in an MJ Research thermocycler.

The amplified products were analysed in 1.5\% agarose gel containing ethidium bromide and observed using a DNA transilluminator (Gel doc system, Hero Lab).

Results and discussion. Fig. 1 shows the presence of multiple occlusion bodies of MBV inside the enlarged nuclei of several hepatopancreatic cells. The infected nuclei were found to be in large numbers with $53 \%$ of the hepatopancreatocytes affected. The percentage increase in the volume of the infected nuclei was estimated to be $430 \%$. Based on the criteria outlined by Lightner et al. (1983), the severity index of the infection was judged to be Grade 4. Postlarvae, from the same hatchery tank were positive for MBV by non-nested PCR (Fig. 2). Histopathological sections of apparently healthy postlarvae did not show the presence of occlusion bodies. However, they were positive for MBV by nested PCR showing a $361 \mathrm{bp}$ band (Fig. 2). It is well known that PCR is a highly sensitive method for detection of target DNA and therefore it was not surprising to find that histopathologically negative samples gave a positive reaction by nested PCR.

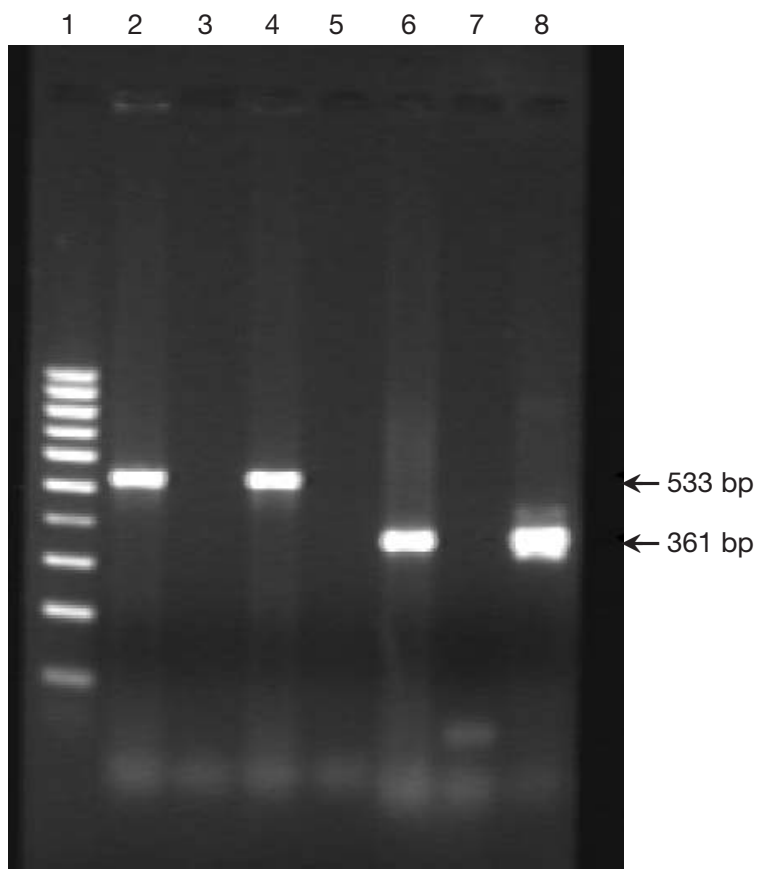

Fig. 2. Penaeus monodon. PCR amplification of MBV using templates prepared from hatchery-reared $P$. monodon postlarvae (PL8-PL10). Lane 1: 100 bp DNA ladder. Lanes 2-5: non-nested PCR products. Lane 2: positive control; Lane 3: negative control; Lane 4: infected postlarvae; Lane 5: apparently healthy postlarvae. Lanes 6-8: nested PCR products. Lane 6: positive control; Lane 7: negative control; Lane 8: apparently healthy postlarvae 
Strongly basophilic inclusion bodies indicative of hepatopancreatic parvovirus (HPV) were also observed in the nuclei of hepatopancreatic cells in histological sections that showed occlusions typical of MBV. Although external signs of HPV may be non-specific, Lightner et al. (1992) reported that in severe infections of juvenile shrimp, the signs may include a whitish and atrophied hepatopancreas, poor growth rate, anorexia, reduced preening activity resulting in increased susceptibility to surface and gill fouling, occasional opacity of abdominal muscles and secondary infections by opportunistic pathogens like Vibrio spp. Indeed, the infected postlarvae showed a whitish hepatopancreas, poor growth, anorexia and reduced preening activity. Usually HPV infection is observed in growout ponds (Lightner 1996, Flegal et al. 1999) and has not been reported so far in hatchery-reared larvae (Sukhumsirichart et al. 1999). However, its presence in postlarvae (PL50) in outdoor nurseries has been reported (Flegel et al. 1995). Therefore, the present study is significant in that it is the first record of the presence of HPV in hatchery-reared, early postlarvae (PL8-PL10). The study further indicates the possibility that HPV may be a major problem in hatcheries, possibly when present with other viruses.

It is well documented that the white spot virus has a wide geographical and a broad host range (Lo et al. 1996, Wang et al. 1998, Rajendran et al. 1999, Hossain et

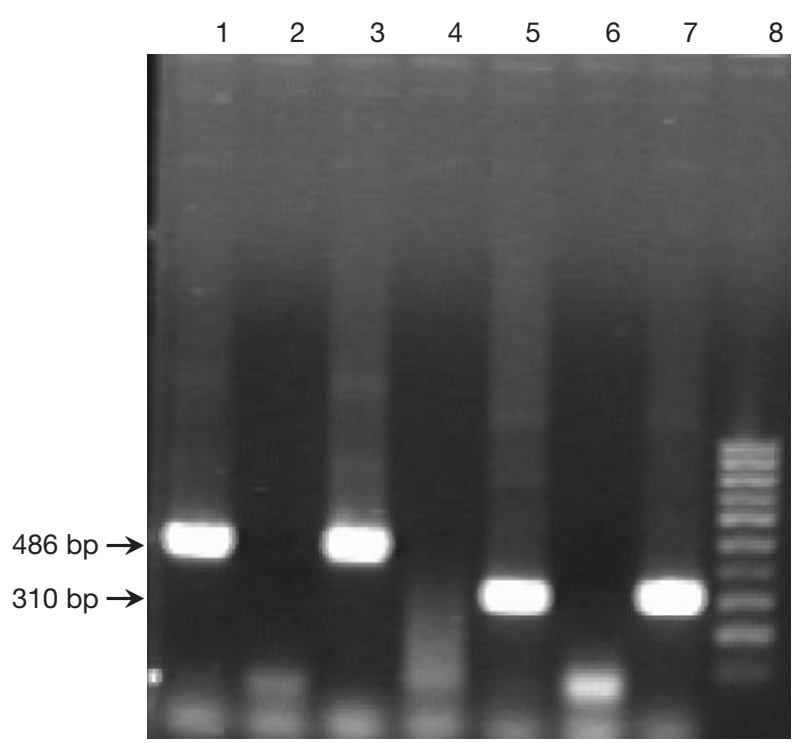

Fig. 3. Penaeus monodon. PCR amplification of WSSV using DNA templates prepared from hatchery-reared $P$. monodon postlarvae (PL8-PL10). Lanes 1-4: non-nested PCR products. Lane 1: positive control; Lane 2: negative control; Lane 3: infected postlarvae; Lane 4: apparently healthy postlarvae. Lanes 5-7: nested PCR products. Lane 5: positive control; Lane 6: negative control; Lane 7: apparently healthy postlarvae. Lane 8: 100 bp DNA ladder al. 2001). In India, a high incidence of the virus has been reported from hatchery samples of larvae in which it may be present in a latent/dormant form without causing mortality (Otta et al. 1999). However, if the virus load is high, it is possible that it will result in disease outbreaks and consequent mortalities (Tsai et al. 1999, Peng et al. 2001). In the present study, the postlarvae from the affected tanks were positive for WSSV by non-nested PCR while those from the healthy tanks (not showing mortality) were positive only by nested PCR (Fig. 3).

We suspect that the viruses detected originated from the broodstock used to produce the postlarvae and this would suggest that the brooders may have had multiple infections. Hence, there could have been either vertical or horizontal transfer of viruses to the postlarvae. Many captured wild shrimp in India have been found positive for MBV (authors' unpubl. data) and WSSV (Otta et al. 1999, Hossain et al. 2001). Though there are no published reports, it is possible that many of these wild broodstock also carry HPV. Therefore it is very important to screen brooders for viruses before they are used in hatcheries.

Though mortality of shrimp larvae due to MBV has been reported in many countries (Baticados et al. 1991, Lightner et al. 1992), it has also been suggested that MBV is relatively well tolerated by Penaeus monodon (Fegan et al. 1991). HPV has not been reported hitherto as the cause of larval mortality in hatcheries. However, it has been suggested (Flegel et al. 1999) that HPV is correlated with retarded growth. Though detected in larvae, there is no evidence either that WSSV has been responsible for larval mortality.

Chantanachookin et al. (1993) reported triple infection with yellow head virus (YHV), HPV and MBV in Penaeus monodon from ponds. They noted that only the presence of YHV was correlated with mortality. However, in the present case, 3 viruses (MBV, HPV, and WSSV) were found in tanks showing mortality. Samples from tanks without mortality showed the presence of MBV and WSSV by nested PCR only. This suggests that the mortality in postlarval tanks was not due to a single virus and it is quite possible that the cumulative effect of all 3 was responsible for the observed mortality.

Acknowledgements. The financial support from DOD-OSTC, Govt. of India, for the research project on the study of marine viruses along the west coast of India is gratefully acknowledged.

\section{LITERATURE CITED}

Baticados MCL, Pitogo CL, Paner MG, de la Pena LD, Tendencia EA (1991) Occurrence and pathology of Penaeus monodon baculovirus infection in hatcheries and ponds in the Philippines. Isr J Aquacult Bamidgeh 43:35-41 
Belcher CR, Young PR (1998) Colourimetric PCR-based detection of monodon baculovirus in whole Penaeus monodon postlarvae. J Virol Methods 74:21-29

Bell TA, Lightner DV (1988) A handbook of normal penaeid shrimp histology. World Aquaculture Society, Baton Rouge, LA, p 2-3

Chantanachookin C, Boonyaratpalin S, Kasornchandra J, Direkbusarakom S, Ekpanithanpong U, Supamataya K, Sriurairatana S, Flegel TW (1993) Histology and ultrastructure reveal a new granulosis-like virus in Penaeus monodon affected by yellow-head disease. Dis Aquat Org 17:145-157

Chong YC, Loh H (1984) Hepatopancreas chlamydial and parvoviral infections of farmed marine prawns in Singapore. Singapore Vet J 9:51-56

Fegan DF, Flegel TW, Sriurairatana S, Waiakrutra M (1991) The occurrence, development and histopathology of monodon baculovirus in Penaeus monodon in Southern Thailand. Aquaculture 96:205-217

Flegel TW, Fegan DF, Kongsom S, Vuthikomudomkit S and 5 others (1992) Occurrence, diagnosis and treatment of shrimp diseases in Thailand. In: Fulks W, Main KL (eds) Diseases of cultured penaeid shrimps in Asia and the United States. The Oceanic Institute, Honolulu, HI, p 74-75

Flegel TW, Fegan DF, Sriurairatana S (1995) Environmental control of infectious shrimp diseases in Thailand. In: Shariff M, Arthur JR, Subasinghe RP (eds) Diseases in Asian aquaculture II. Fish Health Section, Asian Fisheries Society, Manila, p 65-79

Flegel TW, Thamavit V, Pasharawipas T, Alday-Sanz V (1999) Statistical correlation between severity of hepatopancreatic parvovirus (HPV) infection and stunting of farmed black tiger shrimp ( $P$. monodon). Aquaculture 174: 197-206

Fulks W, Main KL (eds) (1992) Diseases of cultured penaeid shrimp in Asia and the United States. Proceedings of a workshop in Honolulu, Hawaii. The Oceanic Institute, Honolulu, HI, p 6

Hossain Md S, Chakraborty A, Joseph B, Otta SK, Karunasagar I, Karunasagar I (2001) Detection of new hosts for white spot syndrome virus of shrimp using nested polymerase chain reaction. Aquaculture 198:1-11

Karunasagar I, Pai R, Malathi GR, Karunasagar I (1994) Mass mortality of Penaeus monodon larvae due to antibiotic resistant Vibrio harveyi infection. Aquaculture 128: 203-209

Leung PS, Tran LT (2000) Predicting shrimp disease occurrence: artificial neural networks vs. logistic regression. Aquaculture 187:35-49

Editorial responsibility: Timothy Flegel, Bangkok, Thailand
Lightner DV (ed) (1996) A hand book of shrimp pathology and diagnostic procedure for diseases of penaeid shrimp. World Aquaculture Society, Baton Rouge, LA

Lightner DV, Redman RM (1985) A parvo-like virus disease of penaeid shrimp. J Invertebr Pathol 45:47-53

Lightner DV, Redman RM, Bell TA (1983) Observations on the geographic distribution, pathogenesis and morphology of the baculovirus from Penaeus monodon Fabricius. Aquaculture 32:209-233

Lightner DV, Bell TA, Redman RM, Mohney LL, Natividad JM, Rukyani A, Poernomo A (1992) A review of some major diseases of economic significance in Penaeid prawns/shrimps of the Americas and Indo-Pacific. In: Shariff M, Subasinghe RP, Arthur JR (eds) Diseases in Asian aquaculture I. Proceedings of the first symposium on diseases in Asian aquaculture, Indonesia. Fish Health Section, Asian Fisheries Society, Manila, p 57-80

Lo CF, Ho CH, Peng SE, Chen CH and 7 others (1996) White spot syndrome baculovirus (WSBV) detected in cultured and captured shrimps, crabs and other arthropods. Dis Aquat Org 27:215-225

Otta SK, Shubha G, Joseph B, Chakraborty A, Karunasagar I, Karunasagar I (1999) Polymerase chain reaction (PCR) detection of white spot syndrome virus (WSSV) in cultured and wild crustaceans in India. Dis Aquat Org 38: $67-70$

Peng SE, Lo CF, Lin SC, Chen LL, Chang YS, Liu KF, Su MS, Kou GH (2001) Performance of WSSV-infected and WSSV-negative Penaeus monodon postlarvae in culture ponds. Dis Aquat Org 46:165-172

Rajendran KV, Vijayan KK, Santiago TC, Krol RM (1999) Experimental host range and histopathology of white spot syndrome virus (WSSV) infection in shrimp, prawns, crabs and lobsters from India. J Fish Dis 22:183-191

Ramasamy P, Brennan GP, Jayakumar R (1995) A record and prevalence of monodon baculovirus from postlarval Penaeus monodon in Madras, India. Aquaculture 130: 129-135

Sukhumsirichart W, Wongteerasupaya C, Boonsaeng V, Panyim S, Sriurairatuna S, Withyachumnarnkul B, Flegel TW (1999) Characterization and PCR detection of hepatopancreatic parvovirus (HPV) from Penaeus monodon in Thailand. Dis Aquat Org 38:1-10

Tsai MF, Kou GH, Liu HC, Liu KF and 5 others (1999) Longterm presence of white spot syndrome virus (WSSV) in a cultivated shrimp population without disease outbreaks. Dis Aquat Org 38:107-114

Wang YC, Lo CF, Chang PS, Kou GH (1998) Experimental infection of white spot baculovirus in some cultured and wild decapods in Taiwan. Aquaculture 164:221-231

Submitted: July 2, 2001; Accepted: December 7, 2001

Proofs received from author(s): March 8, 2002 